\title{
NUTRACEUTICAL FORMULATIONS CONTAINING GLUCOSAMINE AND CHONDROITIN SULPHATE IN THE TREATMENT OF OSTEOARTHRITIS: EMPHASIS ON CLINICAL EFFICACY AND FORMULATION CHALLENGES
}

\author{
AHMED M. AGIBA \\ Research and Development Department, SIGMA Pharmaceutical Industries, Egypt \\ Email: ahmed.agiba@gmail.com
}

Received: 27 Nov 2016, Revised and Accepted: 23 Jan 2017

\begin{abstract}
Osteoarthritis $(\mathrm{OA})$ is essentially a debilitating disease symptomatized by a gradual loss of articular joint cartilage, causing painful impairment among the population of different ages, particularly patients over the age of $50 \mathrm{y}$. Nutraceuticals; namely glucosamine and chondroitin have been widely used in the treatment of OA. The chondroprotective properties of the aforementioned agents have been reported, allowing the repair and recovery of the articular surface in $\mathrm{OA}$. The purpose of this review article is to report the current evidence for the use of glucosamine and chondroitin sulphate in the treatment of knee $\mathrm{OA}$ with emphasis on their indications for clinical use, effectiveness and safety. It also highlights the role of some advanced formulation technologies in optimizing the delivery of those drugs.
\end{abstract}

Keywords: Osteoarthritis, Glucosamine, Chondroitin, Clinical use, Formulation technologies

(C) 2016 The Authors. Published by Innovare Academic Sciences Pvt Ltd. This is an open access article under the CC BY license (http://creativecommons.org/licenses/by/4.0/) DOI: http://dx.doi.org/10.22159/ijcpr.2017v9i2.17380

\section{INTRODUCTION}

Osteoarthritis (OA), also known as degenerative joint disease, degenerative arthritis or osteoarthrosis, is the most common musculoskeletal disease affecting the whole synovial joint [1]. It is believed that cartilage is not the sole organ being affected by OA, but also ligaments, synovia and bone, which undergo metabolic and structural modifications as the disease progresses.

$\mathrm{OA}$ is the prominent form of arthritis; its prevalence increases dramatically with age [2], and can lead to significant pain, reduced range of motion and increased disability [3]. As a result, it is considered a disabling arthritic condition that causes activity limitation and reduced quality of life among the population over the age of fifty. It has been estimated that each year, more than $75 \%$ of individuals over the age of 65 present with $\mathrm{OA}$ in one or more joints [4]. In addition, some studies have shown that $12.1 \%$ of American individuals over the age of $25 \mathrm{y}$ show clinical symptoms of $\mathrm{OA}$ [5]

OA is characterised by a gradual loss of articular cartilage in synovial joints, causing articular cartilage destruction with subsequent loss of joint space. Clinical manifestations of this disease are joint pain and damage, stiffness, effusion, instability, and ultimately, deformity. Genetic and nutritional factors mainly contribute to the etiology of $\mathrm{OA}$, in addition to other biological, biochemical and mechanical factors $[5,6]$. It is believed that the primary OA is characterized by mechanical, repetitive overloading of the articular cartilage, which leads to a vicious circle of inflammation, degradation and loss of joint cartilage. This inflammation is mainly attributed to the secretion of interleukin-1 (1L-1) and a monocyte-derived cytotoxin (i.e. tumor necrosis factor TNF $\alpha$ ), which increase metalloproteinases and nitric oxide synthase production, which are the main catabolic agents in joint cartilage lesions [6-8].

A demand for OA treatment is gradually increasing each year due to the rise in its prevalence caused by the dramatic increase in average life expectancy among the population, with a higher degree of degenerative joint arthritis [9]. The pathogenic complexity of OA creates a challenge for diagnosis and management of this disease, which mainly relies on symptomatic treatment and improvement of patients' functional abilities. Treatment mainly includes a combination of pharmacological and non-pharmacological methods (physiotherapy, occupational therapy, weight loss and exercise). In addition, alternative therapies, such as; homeopathy, acupuncture, phytotherapeutic medications; and surgical methods are also utilized [10]. The pharmacological therapy is directed towards the prevention of pain and improvement of function among patients with $\mathrm{OA}$. The first choice medications in the pharmacological treatment of OA-related pain include analgesics (acetaminophen and paracetamol) and non-steroidal antiinflammatory drugs (NSAIDs) [11, 12]. However, some studies have indicated that NSAIDs are only used to treat symptoms without correction of the degenerative disorder of the connective tissue. Furthermore, the long-term use of NSAIDs causes potential adverse effects on the gastrointestinal and cardiovascular systems, which are mainly popular among elderly patients [13]. Therefore it can be deduced that medical treatments available for $\mathrm{OA}$ are moderately effective and are mostly directed at short-term pain relief, In addition, side effects of these treatments can be quite significant.

The need for the development of new drug treatments for $\mathrm{OA}$ that could systemically relieve pain and potentially modify structural damage has emerged. Nutraceuticals such as glucosaminoglycans (GAGs) have recently been introduced as biological alternatives for drug treatment since there is a substantial interest in the chondroprotective effects of GAGs such as glucosamine sulphate and chondroitin sulphate. Both of these drugs have been approved as agents that modify the natural history of OA [14].

Glucosamine sulphate and chondroitin sulphate are natural nutraceutical compounds which are known as cartilage precursors. They are not only considered as symptomatic drugs for $\mathrm{OA}$, but they also have a disease-modifying potential, hence, they have gained worldwide popularity over the last decades [15]. This review article focuses on those two compounds for the treatment of OA.

Preparations, dosages, bioavailability and pharmacokinetics of glucosamine

Glucosamine, 2-amino-2-deoxy-D-glucose (C6H14NoO5), is a monosaccharide with a molecular weight (197.2 Da). It is naturally produced in the body and acts as a precursor for the biosynthesis of glycosylated lipids and proteins. Functionally, glucosamine is a prominent precursor for GAGs or mucopolysaccharides and is structurally belonging to glycoproteins and proteoglycans. Glucosamine helps in the maintenance of healthy joint function, primarily targeting people suffering from OA. Although glucosamine has not been approved yet by FDA as a drug of choice in the treatment of $\mathrm{OA}$, it is prescribed as a first-line drug in OA treatment in Europe [16]. 
There are different forms of glucosamine in the market. Glucosamine preparations are either extracted from chitin (from crustacean shells) by acid hydrolysis (and thus patients with shellfish allergies should be cautioned to avoid the use of glucosamine) or chemically synthesised. Glucosamine is a weak organic base, which must first be stabilised as a salt. There are three forms of glucosamine commonly available on the market: glucosamine hydrochloride (from crab shells), glucosamine sulphate (from shrimp shells) and chemically synthesised glucosamine (as sulphate form), as illustrated in (fig. 1, 2).

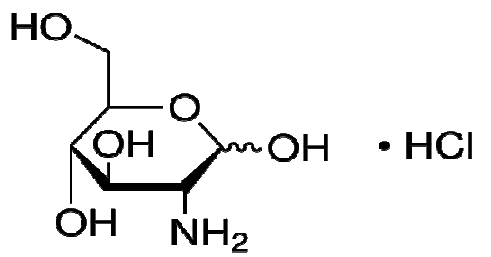

Fig. 1: Chemical structure of glucosamine $\mathrm{HCl}$

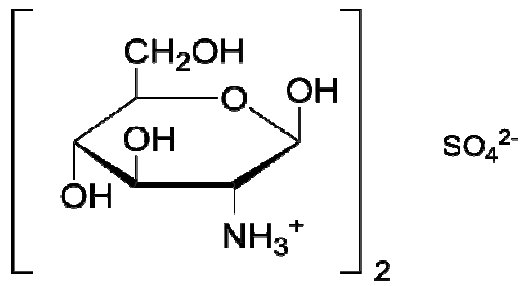

Fig. 2: Chemical structure of glucosamine $\mathrm{So}_{4}$

The absolute daily dosing of glucosamine varies according to the preparation type, owing to the differences of the molecular size of the associated salt. The recommended daily dosing of glucosamine generally ranges from $1250 \mathrm{mg} 1500 \mathrm{mg}$. Single oral dose of glucosamine $(1500 \mathrm{mg})$ approximately produces plasma concentration of $10 \mu \mathrm{mol}$, while taking a dose $(500 \mathrm{mg})$ three times daily produces approximately a plasma concentration of $3 \mu \mathrm{mol}$ [17].

Several studies were conducted to determine the absorption, distribution, and metabolism of glucosamine. Clinical pharmacokinetics of oral dose administration of glucosamine $\mathrm{HCl}$ at significant doses was evaluated, and glucosamine was shown to be bioavailable in the synovia and serum of beagles and horses $[18,19]$. Uptake of a radiolabeled dose of glucosamine sulphate by articular cartilage following an oral dose was also detected in both rats and dogs $[20,21]$ and in human volunteers [22]. Absorption of radiolabeled glucosamine sulphate was estimated to be $90 \%$, but in turn, there was a significant first-pass effect or pre-systemic metabolism resulting in a bioavailability of $26-44 \%$ [22]. Animal studies have also shown a bioavailability of approximately $19 \%$ in rats [23]. Glucosamine was estimated to have a half-life of $15 \mathrm{~h}$ following oral dosing [24]. Glucosamine sulphate pharmacokinetics was linear up to the standard dosing of glucosamine $(1500 \mathrm{mg} /$ day $)$, while higher doses did not result in a proportionally higher increase in glucosamine maximum concentration [24].

\section{Preparations, dosages, bioavailability and pharmacokinetics of} chondroitin sulphate

Chondroitin is considered a complex macromolecule. It is a natural polymer of $\alpha$-disaccharide with an alternating sequence of D-glucose and $\mathrm{N}$-acetyl-galactosamine-4-sulphate or 6-sulphate residues linked together through different bonds. It is a high molecular weight GAG with a molecular weight (10000-50000 Da). There are two available forms of chondroitin sulphate in hyaline cartilage depending on the position of the sulphated monosaccharide; chondroitin-4-sulphate and chondroitin-6-sulphate (fig. 3, 4). Interestingly, the more superficial cartilage contains higher proportions of chondroitin-6-sulphate, while the newer deeper cartilage contains more chondroitin-4-sulphate [25]. Ratios of chondroitin-6-sulphate to chondroitin-4-sulphate in cartilage with osteoarthritis were substantially lower, but the clinical significance of this finding is unclear [26].

Functionally, chondroitin sulphate is a sulphated GAG, and structurally, it is found attached to proteins as part of a proteoglycan. Chondroitin sulphate is an essential component of joint cartilage which also helps to inhibit the enzymes that cause its decomposition. It is approved in Europe as a symptomatic slowacting drug for $\mathrm{OA}$ [16]. It is marketed together with glucosamine in different concentrations [27].

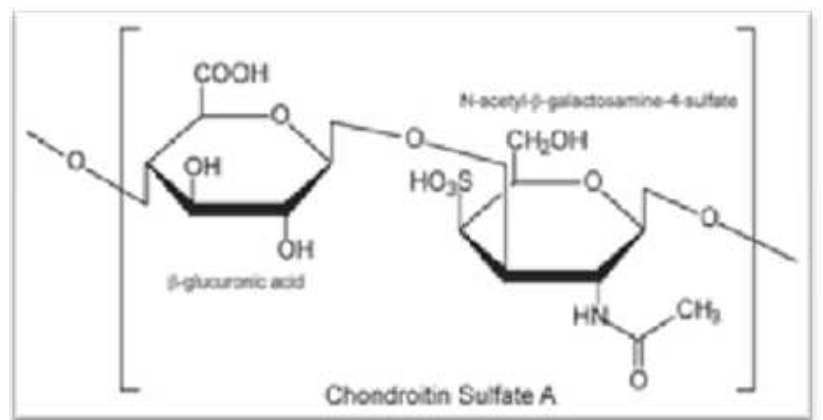

Fig. 3: Chemical structure of chondroitin-4-So 4

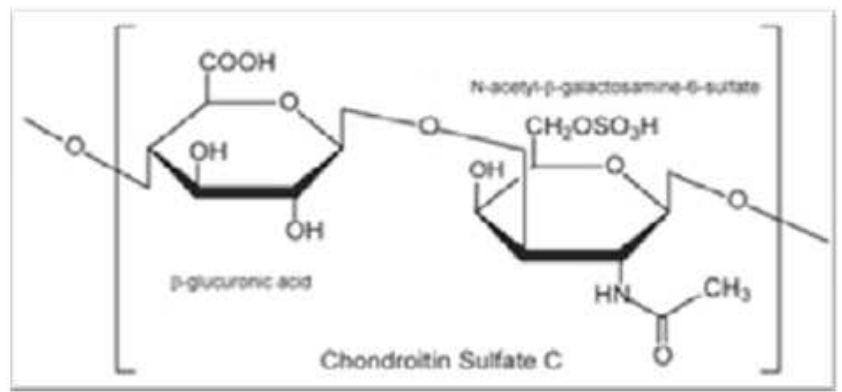

Fig. 4: Chemical structure of chondroitin-6-So4

Chondroitin sulphate sodium salt is the most commonly used salt of chondroitin sulphate in oral preparations. It is sold in the United States as a dietary supplement and does not require a prescription. It either comes from bovine or porcine tracheal cartilage or occasionally from fish or avian cartilage. Although no enough dosing studies have been conducted, recommended daily dosages of chondroitin sulphate are between 800 to $1200 \mathrm{mg}$ [17].

The oral bioavailability of chondroitin sulphate ranges from 5 to $15 \%$ with a half-life of $6 \mathrm{~h}$ and plasma peak levels from 2 to $28 \mathrm{~h}$ after oral administration. A published study on the human pharmacokinetics of clinically relevant doses of both glucosamine $\mathrm{HCl}$ and chondroitin sulphate sodium salt did not reveal a detectable difference of circulating endogenous plasma levels of chondroitin sulphate after a single oral dose of $1200 \mathrm{mg}$ at all-time intervals 0.25 to $36 \mathrm{~h} \mathrm{[28].}$

\section{Modes of action of glucosamine and chondroitin in $\mathrm{OA}$}

The possible modes of action of glucosamine and chondroitin in the treatment of $\mathrm{OA}$ are described in (table 1). Glucosamine and chondroitin promote the biosynthesis of proteoglycan and inhibit the degradative enzymes which are responsible for the premature breakdown of cartilage in OA $[29,30]$. 
Table 1: Possible modes of action of glucosamine and chondroitin in the treatment of $\mathrm{OA}$

\begin{tabular}{ll}
\hline Glucosamine & Chondroitin \\
\hline Inhibits cytokines (interleukin-1 $\beta$ ) & Inhibits cytokines (interleukin-1 $\beta$ ) \\
Inhibits proteases (matrix metalloproteinase and collagenase) & Inhibits proteases (collagenase) \\
Interferes with binding of nuclear factor ${ }_{\mathrm{k}} \mathrm{B}$ & Increases bone mineralisation and repair \\
Reduces prostaglandin $\mathrm{E}_{2}$ production & Increases viscosity of synovial fluid \\
Increases proteoglycan synthesis & Increases proteoglycan synthesis by chondrocytes \\
\hline
\end{tabular}

\section{Clinical studies conducted on glucosamine in the treatment of $\mathrm{OA}$}

Efficacy of glucosamine in the treatment of OA was reported in earlier clinical trials provided by Rottapharm [31]. In general, these studies declared a positive effect of glucosamine both symptomatically and radiographically in the treatment of OA. The first study [32] evaluated and studied 212 patients with knee OA and randomized a group to receive a daily dose of glucosamine sulphate, $1500 \mathrm{mg}$, versus placebo. Western Ontario and McMaster Universities OA Index (WOMAC) scores were used to evaluate pain and function as percent change on a visual analog scale (VAS).

There was a significant improvement in pain and function, but no improvement in stiffness. The second study [33] evaluated and studied 202 patients with knee OA, using a daily dose of glucosamine sulphate, $1500 \mathrm{mg}$, concluding a significant change in WOMAC scores for pain, function and stiffness as well. Towheed et al. [34] evaluated the role of glucosamine in the treatment of OA, including 9 trials of glucosamine prepared using Rotta preparation method and 8 trials using non-Rotta preparation method. The results showed a clinical significance of improvement in pain relief and efficacy in function with a significant change in Lequesne index (assessing the severity of OA through evaluation of daily activity and function). In addition, there was a significant improvement in WOMAC scores reported in subgroup patients taking glucosamine prepared by Rotta preparation method. The Glucosamine/chondroitin Arthritis Intervention Trial (GAIT) [27] randomly evaluated 1583 patients suffering from knee OA and randomized them to receive a daily dose of glucosamine $\mathrm{HCl}(1500$ $\mathrm{mg})$, sodium chondroitin sulphate $(1200 \mathrm{mg})$, both at the same doses, celecoxib (200 mg), or placebo for $24 \mathrm{w}$. Results showed a $20 \%$ decrease in WOMAC scores for pain after $24 \mathrm{w}$. Despite the finding that glucosamine had a significant effect on the subgroup of patients with moderate to severe pain; interpretation of this result was limited by the small number of patients in this subgroup. However, a GAIT study which randomly evaluated 662 patients with knee $\mathrm{OA}$ and treated with the same treatments, declared no clinical improvement in WOMAC scores for pain and function versus placebo [35]. Although glucosamine and celecoxib showed an improvement in pain and function, they did not reach the statistical significance. Tables 2 and 3 summarize the randomized clinical trials (RCTs) and meta-analyses of glucosamine sulphate and $\mathrm{HCl}$ salts respectively.

Table 2: Summary of randomized clinical trials (RCTs) and meta-analyses studies of glucosamine sulphate (GS)

\begin{tabular}{|c|c|c|c|c|c|}
\hline Reference & $\begin{array}{l}\text { No. of } \\
\text { patients }\end{array}$ & Duration & Dosage regimen & Parameters evaluated & Results and conclusions \\
\hline [36] & 200 & $4 w$ & $\begin{array}{l}400 \mathrm{mg} \text { GS } 3 \text { times } \\
\text { daily vs ibuprofen }\end{array}$ & Lequesne's severity index & $\begin{array}{l}\text { GS was as effective as ibuprofen and better } \\
\text { tolerated }\end{array}$ \\
\hline$[37]$ & 252 & $4 w$ & $\begin{array}{l}500 \mathrm{mg} \text { GS } 3 \text { times } \\
\text { daily vs placebo }\end{array}$ & Lequesne's severity index & $\begin{array}{l}\text { GS was significantly more effective than } \\
\text { placebo in revealing OA symptoms }\end{array}$ \\
\hline$[38]$ & 155 & $6 \mathrm{w}$ & $\begin{array}{l}400 \mathrm{mg} \text { GS (IM) } 2 \\
\text { times daily for } 6 \mathrm{w}\end{array}$ & Lequesne's severity index & $\begin{array}{l}\text { Duration was too short to make significant } \\
\text { long-term conclusions }\end{array}$ \\
\hline$[32]$ & 212 & $3 y$ & $\begin{array}{l}1500 \mathrm{mg} \text { GS once } \\
\text { daily vs placebo }\end{array}$ & $\begin{array}{l}\text { WOMAC pain scores and minimal } \\
\text { joint space }\end{array}$ & $\begin{array}{l}\text { GS protected the joint space against the } \\
\text { narrowing effects of } \mathrm{OA}\end{array}$ \\
\hline [39] & 80 & $6 \mathrm{mo}$ & $\begin{array}{l}1500 \mathrm{mg} \text { GS once } \\
\text { daily vs placebo }\end{array}$ & $\begin{array}{l}\text { Pain scores on visual analog } \\
\text { scale, WOMAC pain scores and } \\
\text { McGill pain index }\end{array}$ & $\begin{array}{l}\text { No statistically significant improvement over } \\
\text { placebo as a symptom modifier }\end{array}$ \\
\hline [33] & 202 & $3 y$ & $\begin{array}{l}1500 \mathrm{mg} \mathrm{GS} \text { once } \\
\text { daily }\end{array}$ & $\begin{array}{l}\text { Lequesne's index, WOMAC pain } \\
\text { scores and minimal joint space }\end{array}$ & $\begin{array}{l}\text { Statistically significant effects of GS on both } \\
\text { radiographic progression and WOMAC } \\
\text { scores }\end{array}$ \\
\hline$[40]$ & 212 & $3 y$ & $\begin{array}{l}1500 \mathrm{mg} \mathrm{GS} \text { once } \\
\text { daily }\end{array}$ & Joint space narrowing & $\begin{array}{l}\text { Disease-modifying effects were found in } \\
\text { postmenopausal women }\end{array}$ \\
\hline$[41]$ & 137 & $6 \mathrm{mo}$ & $\begin{array}{l}1500 \mathrm{mg} \text { GS once } \\
\text { daily vs placebo }\end{array}$ & $\begin{array}{l}\text { Lequesne's index and WOMAC } \\
\text { pain scores }\end{array}$ & $\begin{array}{l}\text { No clinical evidence of symptomatic benefits } \\
\text { from continued GS treatment during this } 6 \\
\text { mo study }\end{array}$ \\
\hline [42] & 414 & $3 y$ & $\begin{array}{l}1500 \mathrm{mg} \text { GS once } \\
\text { daily vs placebo }\end{array}$ & $\begin{array}{l}\text { Minimal joint space width and } \\
\text { WOMAC pain scores }\end{array}$ & $\begin{array}{l}\text { GS showed non-statistical effects compared } \\
\text { to placebo }\end{array}$ \\
\hline [43] & 318 & $6 \mathrm{mo}$ & $\begin{array}{l}1500 \mathrm{mg} \text { GS once } \\
\text { daily vs placebo }\end{array}$ & $\begin{array}{l}\text { Lequesne's index and WOMAC } \\
\text { pain scores }\end{array}$ & $\begin{array}{l}\text { GS found to be better than placebo and } \\
\text { acetaminophen }\end{array}$ \\
\hline
\end{tabular}

Table 3: Summary of randomized clinical trials (RCTs) and meta-analyses studies of glucosamine HCl (GH)

\begin{tabular}{|c|c|c|c|c|c|}
\hline Reference & $\begin{array}{l}\text { No. of } \\
\text { patients }\end{array}$ & Duration & Dosage regimen & $\begin{array}{l}\text { Parameters } \\
\text { evaluated }\end{array}$ & Results and conclusions \\
\hline$[44]$ & 101 & $8 w$ & GH vs placebo & $\begin{array}{l}\text { WOMAC pain } \\
\text { scores }\end{array}$ & $\begin{array}{l}\text { No statistically significant changes in WOMAC pain scores, } \\
\text { i.e. GH was as effective as placebo }\end{array}$ \\
\hline [45] & 205 & $12 \mathrm{w}$ & $\begin{array}{l}15 \text { gm GH once daily } \\
\text { vs placebo }\end{array}$ & $\begin{array}{l}\text { WOMAC pain } \\
\text { scores }\end{array}$ & $\begin{array}{l}\text { GH was safe but not more effective than placebo in } \\
\text { relieving symptoms of knee arthritis }\end{array}$ \\
\hline
\end{tabular}


Clinical studies conducted on chondroitin sulphate in the treatment of $\mathrm{OA}$

Efficiency of chondroitin sulphate over placebo for the treatment of OA was reported in clinical studies as well. GAIT [46] was the biggest and most rigorous study designed to evaluate the efficiency of chondroitin sulphate in symptomatic knee OA. A post-hoc analysis of GAIT demonstrated a potential benefit of chondroitin sulphate treatment on joint swelling [46]. Reichenbach et al. [47] published a meta-analysis study assessing the effect of chondroitin sulphate on pain in knee or hip OA. They reported substantial heterogeneity among trials, rendering the interpretation of results conflicting. A published RCT which included 662 patients evaluated the effect of chondroitin sulphate on the structural progression of knee OA using VAS and WOMAC. Pain as a secondary outcome was measured over 2 y. Results showed a significant improvement in pain relief; although statistical significance did not persist for long-term [48]. Messier et al. [49] evaluated 89 patients with knee OA over 12 mo by measuring the effects of a combinatorial daily dose of $1500 \mathrm{mg}$ glucosamine and $1200 \mathrm{mg}$ chondroitin sulphate along with exercise over the placebo. The results did not show any difference in pain and function between patients taking drugs over placebo.

Another study [50] evaluated 100 patients with knee $0 A$ receiving a combinatorial daily dose of $250 \mathrm{mg}$ glucosamine sulphate and 200 mg chondroitin sulphate by using JSW and Lequesne index over 12 mo. Results of this study showed significant effects on patients taking drugs over placebo. Summary of randomized clinical trials and meta-analyses of chondroitin sulphate alone or in combination with glucosamine is illustrated in (tables 4,5 ), respectively.

Table 4: Summary of randomized clinical trials (RCTs) and meta-analyses studies of chondroitin sulphate (CS)

\begin{tabular}{|c|c|c|c|c|c|}
\hline References & $\begin{array}{l}\text { No. of } \\
\text { patients }\end{array}$ & Duration & Dosage regimen & Parameters evaluated & Results and conclusions \\
\hline$[51]$ & 80 & $6 \mathrm{mo}$ & $\begin{array}{l}400 \mathrm{mg} \text { CS twice daily vs } \\
\text { placebo }\end{array}$ & $\begin{array}{l}\text { Lequesne's index, and } \\
\text { visual analog scale }\end{array}$ & $\begin{array}{l}\text { A statistically significant improvement in } \\
\text { patients taking CS over placebo, with no } \\
\text { difference in side effects }\end{array}$ \\
\hline$[52]$ & 127 & $3 \mathrm{mo}$ & $\begin{array}{l}1200 \mathrm{mg} \text { CS vs } 400 \mathrm{mg} \\
\text { CS } 3 \text { times daily vs } \\
\text { placebo }\end{array}$ & $\begin{array}{l}\text { Lequesne's index, and } \\
\text { visual analog scale }\end{array}$ & $\begin{array}{l}\text { A reduction in Lequesne's index and } \\
\text { spontaneous joint pain scores over placebo }\end{array}$ \\
\hline [53] & 104 & $1 \mathrm{y}$ & 800 mg CS vs placebo & $\begin{array}{l}\text { Lequesne's index, and } \\
\text { joint space loss }\end{array}$ & $\begin{array}{l}\text { A significant improvement in patients taking CS } \\
\text { over placebo }\end{array}$ \\
\hline$[54]$ & 130 & $6 \mathrm{mo}$ & $\begin{array}{l}1 \text { gm CS once daily vs } \\
\text { placebo for } 3 \text { mo }\end{array}$ & Lequesne's index & $\begin{array}{l}\text { Lequesne's index significantly improved and } \\
\text { remained elevated after the treatment for } 1 \text { mo }\end{array}$ \\
\hline$[55]$ & 300 & $2 \mathrm{y}$ & CS vs placebo & Joint space loss & $\begin{array}{l}\text { CS reduced the radiographic progression of knee } \\
\text { OA }\end{array}$ \\
\hline [56] & 120 & $1 \mathrm{y}$ & $\begin{array}{l}800 \mathrm{mg} \text { CS once daily for } \\
3 \mathrm{mo}\end{array}$ & Lequesne's index & $\begin{array}{l}\text { A significant improvement in pain and function } \\
\text { in patients taking CS over placebo }\end{array}$ \\
\hline [57] & 300 & $2 y$ & 800 mg CS vs placebo & $\begin{array}{l}\text { Joint space narrowing, } \\
\text { and Lequesne's index }\end{array}$ & $\begin{array}{l}\text { CS retarded the radiographic progression of knee } \\
\text { OA }\end{array}$ \\
\hline [58] & 307 & $6 \mathrm{mo}$ & 1000 mg CS once daily & Lequesne's index & $\begin{array}{l}\text { No significant improvement in patients taking CS } \\
\text { versus placebo }\end{array}$ \\
\hline
\end{tabular}

Table 5: Summary of randomized clinical trials (RCTs) and meta-analyses of combination therapy of glucosamine and chondroitin

\begin{tabular}{|c|c|c|c|c|c|}
\hline Reference & $\begin{array}{l}\text { No. of } \\
\text { patients }\end{array}$ & Duration & Dosage regimen & $\begin{array}{l}\text { Parameters } \\
\text { evaluated }\end{array}$ & Results and conclusions \\
\hline [59] & 90 & $6 \mathrm{mo}$ & $\begin{array}{l}500 \mathrm{mg} \mathrm{GH}, 500 \mathrm{mg} \mathrm{CS} \text { and } \\
\text { Diclofenac Sodium twice daily } \\
\text { for } 1 \mathrm{mo} \text { vs Diclofenac Sodium }\end{array}$ & WOMAC pain scores & $\begin{array}{l}\text { WOMAC score decreased after } 3 \text { mo of the } \\
\text { treatment and } 3 \text { mo after the supplements had } \\
\text { been discontinued. } \\
\text { The combined medications offer a high evidence } \\
\text { of safety and effectiveness in the short-term } \\
\text { treatment of pain with long-lasting effects }\end{array}$ \\
\hline [27] & $>1000$ & $6 \mathrm{mo}$ & $\begin{array}{l}1500 \mathrm{mg} \mathrm{GH} \text { vs } 1200 \mathrm{mg} \text { CS vs } \\
\text { GH plus CS vs } 200 \mathrm{mg} \\
\text { Celecoxib vs placebo }\end{array}$ & $\begin{array}{l}\text { WOMAC pain scores } \\
\text { and other indexes }\end{array}$ & $\begin{array}{l}\text { Celecoxib showed a significant effect on } 6 \text { of the } \\
\text { outcome measures, whereas GH and CS were } \\
\text { found to have a significant effect on } 14 \text { of the } \\
\text { outcome measures }\end{array}$ \\
\hline [49] & 80 & $1 \mathrm{y}$ & $1500 \mathrm{mg} \mathrm{GH}$ and $1200 \mathrm{mg}$ CS & $\begin{array}{l}\text { WOMAC pain scores } \\
\text { and other } \\
\text { parameters } \\
\text { ( } 6 \text { min' walk, knee } \\
\text { strength, and } \\
\text { functional) }\end{array}$ & $\begin{array}{l}\text { No significant difference between groups for the } \\
6 \text {-minutes' walk, knee strength, and functional } \\
\text { over the placebo }\end{array}$ \\
\hline
\end{tabular}

\section{Safety profile of glucosamine and chondroitin}

Safety studies conducted on glucosamine, chondroitin sulphate or their combination were not reported to cause systemic adverse effects compared with other analgesic or non-steroidal anti-inflammatory drugs (NSAIDs) in short or long-term treatments. However, NSAIDs including COX-2 inhibitors for pain relief in $\mathrm{OA}$ is accompanied by increased risk of adverse effects in long-term treatment such as gastrointestinal problems and cardiovascular risks [13]. Furthermore, no evidence of any clinically significant drug interactions for glucosamine or chondroitin was reported as well. This created an increased demand for optimizing the delivery of glucosamine and chondroitin sulphate as safe treatments for OA.

Pharmaceutical strategies to enhance the delivery of glucosamine and chondroitin sulphate

As obvious from the clinical trial results reported in the previous sections of the review article, a discrepancy in the opinions of authors was reported on whether glucosamine and chondroitin are exclusively effective in the treatment of OA upon administration in the conventional ways. The oral delivery of a nutraceutical formulation containing a high dose of chondroitin sulphate and 
glucosamine sulphate remains a challenge owing to the high molecular weight of chondroitin (10000-50000 Da), as well as the extensive hepatic first-pass metabolism of glucosamine sulphate. This leads to low bioavailability ranging from $5-15 \%$ for chondroitin sulphate and $26-44 \%$ for glucosamine sulphate $[22,28]$.

Although different classes of bioenhancer compounds such as surfactants, co-surfactants, bile salts, fatty acids, cyclodextrins, chelators, cellulose derivatives and positively charged polymers [60] have been utilized to enhance the absorption of low permeable hydrophilic drugs by acting on the mucous layer and membrane components or tight junctions of the intestinal epithelium; research studies have shown that the effective intra-articular concentration of glucosamine and chondroitin sulphate could not be achieved by oral route using conventional methods of drug delivery [18,61]. The addition of cellulose derivatives such as carboxymethylcellulose sodium (CMC-Na) and hydroxypropyl methyl cellulose (HPMC) resulted in lower absorption levels of glucosamine in rats [62]. Anionic surfactants like sodium lauryl sulphate (SLS) and non-ionic surfactants like polysorbate 80 (Tween 80 ) have some limitations concerning their systemic use, for example, SLS is highly toxic to the intestinal mucosa, and Tween 80 has an odoriferous smell and very bitter taste [62].

Surprisingly, the addition of positively charged mucoadhesive polymer (chitosan) $0.5 \%(\mathrm{w} / \mathrm{v})$ exhibited a significant effect on glucosamine oral bioavailability [62]; therefore many studies have further been performed to investigate the possible mechanism and role of chitosan in absorption enhancement. Caco-2 permeability studies have shown that chitosan improved absorption of glucosamine by 1.9 to 4.0 fold via the reversible opening of tight cell junctions by binding tightly to the epithelium, inducing a redistribution of F-actin (an important protein that regulates paraceullular flow across epithelia) and occludin proteins [63]. Oral administration of solutions containing glucosamine coated with chitosan (Glu-CH) in rats showed that $0.5 \%(\mathrm{w} / \mathrm{v})$ chitosan exhibited the highest improvement in $\mathrm{C}_{\max }$ (2.8-fold) and $\mathrm{AUC}_{0}$ (2.5-fold) of glucosamine. Furthermore, pharmacokinetic studies in beagle dogs showed much higher bioavailabilities of 313\% for Glu-CH solution and $186 \%$ Glu-CH tablets comparing with their innovator tablets (Welless $^{\mathrm{TM}}$ solution and Voltaflex ${ }^{\mathrm{TM}}$ tablet) [62]. Therefore, chitosan is concluded to be a promising bioenhancer for glucosamine. Chitosan was also used in the formation of hydrogels based on the formation of complexes between chitosan/chondroitin sulphates (CT/CS) then applying as devices for chondroitin release [64]. Chitosan-hyaluroan composite cross-linked with chondroitin sulphate nanoparticles (CH-HYA/nCS) was developed based on simple ionic cross-linking using N,N-(3-dimethylaminopropyl)-Nethyl Carbodiimide (EDC) [65], followed by lyophilisation to obtain the composite sponge [66-68]. CH-HYA/nCS was structurally and physicochemically evaluated showing high porosity $(60-70 \%)$. It also showed high swelling and water uptake properties, owing to the high porosity of the nanocomposite sponges, with high biodegradation profile and cell viability, indicating that CH-HYA/nCS sponge was totally biocompatible. This sponge technique was recommended as a scaffold for chondroitin sulphate release [65].

Another strategy for enhancing the delivery of glucosamine was the entrapment within fatty acid vesicles (FAV) for site-specific delivery of glucosamine sulphate [69]. Oleic acid vesicles were formulated by thin film hydration method followed by ultra-sonication for size reduction. Particle size and zeta potential were evaluated. A Stable FAV formulation was shown to have a particle size range of 100-150 $\mathrm{nm}$ and a zeta potential range of -20 to $-23 \mathrm{mV}$. Pre-formulation studies of different FAV formulations were carried out in correlation with in vivo studies in rats. Results have shown that more than $60 \%$ of the glucosamine was entrapped in FAV. In vitro studies have shown a sustained release and a long-term stability of FAV. In conclusion, FAV exhibits better skin permeation potential and depot characteristics, as well as a reduction in joint inflammation [69].

A smart drug delivery system with controllable properties and high potential regenerative action was designed for targeting the injured site with high selectivity and specificity. Chondroitin sulphate encapsulated in a liposome (L-CS) embedded in a natural polymeric matrix of collagen (COL-L-CS) for the treatment of inflammatory disorders; especially OA was developed [70]. COL-L-CS was fabricated with pore size range between 50 and $200 \mu \mathrm{m}$, provided a favourable cell adhesion and proliferation; furthermore, induced osteogenic behaviour of different cell types [71]. COL-L-CS was formulated by freeze-drying technique, using thin film hydration method for the preparation of L-CS [72] followed by mixing with purified COL in a ratio of 1:1 (w/w) [70], and then frozen under controlled condition [73]. This controlled process resulted in pore formation in a three-dimensional COL sponge matrix. COL-L-CS was structurally, physicochemically and biologically evaluated. Morphologically, it was similar to COL scaffold matrix, showing a network of interconnected COL fibrils unevenly covered with white to the off-white homogenous suspension of L-CS. Structurally, as a network of nanosized COL fibrils decorated with deposits of L-CS at both sides of the sponge matrix. Physically, porosity and density were similar to COL scaffold matrix, but its biodegradability was significantly lower values $(\mathrm{P}<0.05)$. In vitro cytotoxicity testing has shown that the matrix system induced high cell viability and stimulated cell metabolism in L929 cell culture. It highlighted COL-LCS advantage over CS alone (significantly higher $(\mathrm{P}<0.05)$ cytocompatibility in L929 cell culture). In addition, in vitro diffusion testing have shown that the released quantity of CS was significantly lower $(\mathrm{P}<0.05)$ after embedding of $\mathrm{L}-\mathrm{CS}$ inside $\mathrm{COL}$ matrix. In conclusion, COL-L-CS exhibited a potential regenerative action in the treatment of $\mathrm{OA}$, and could be used as a carrier for the delivery of therapeutic agents.

In a recently-published article by Umerska et al. [74], they successfully developed a new type of chondroitin sulfate-based nanoparticles; namely chondroitin sulfate/chitosan (positively and negatively charged), chondroitin sulfate/chitosan/calcitonin, and chondroitin sulfate/calcitonin. Chondroitin sulfate-based nanoparticles offer the advantages of very high drug loading with high efficiency close to $100 \%$. da Silva et al. [75] also developed a novel eco-friendly biocomposite of chondroitin sulfate/poly(vinyl alcohol)/bovine bone powder through cyclic freeze-thawing under mild conditions as a promising biomaterial for potential skin tissue engineering.

\section{DISCUSSION}

$\mathrm{OA}$ is the most common form of arthritis and is considered one of the most frequent causes of morbidity among the population over the age of years. Load-bearing joints (i.e. knee and hip) are considered the most affected organs, and their involvement absolutely gives rise to a high degree of functional limitations of the lower limbs. With increasing life expectancy, treatment of OA should be taken into consideration. In the United States, the scale of medications and supplements for OA treatment has risen from $\$ 86$ billion in 2004 to $\$ 760$ billion in 2013 [76]. The clinical treatment of OA is a matter of debate for many years. Even after many years of study and research, doubts still exists around the efficiency of glucosamine, chondroitin sulphate or both in the treatment of OA. Most studies lately published lack delineation good enough to prove secure conclusions. Recently, several studies confirmed the efficiency of glucosamine and chondroitin in the treatment of OA pain. In these circumstances, European League against Rheumatism (EULAR) confirmed glucosamine and chondroitin as symptomatic slow-acting drugs for the management of OA by modifying the structure of cartilage [77]. American College of Rheumatology (ARC) also recommended glucosamine sulphate and chondroitin sulphate under certain conditions [78]. In contrast, UK's National Institute for Health and Care Excellence (NICE) has recommended that these products mainly should not be used due to economical reasons [78].

\section{CONCLUSION}

$\mathrm{OA}$ is a slowly progressive disease and evidence of disease modification with an intervention may not be apparent for many years. Glucosamine and chondroitin sulphate have individually shown inconsistent efficiency in decreasing OA pain and improving joint function. A combination of oral chondroprotective glucosamine and chondroitin sulphate has proven efficiency in modulating $\mathrm{OA}$ and an excellent safety profile in long-term use. These components are essential substances of the cartilage metabolism and can 
stimulate cartilage regeneration processes in OA. Appropriate methodology and enough clinical studies are needed in order to approve the efficiency of this combination in short-term treatment.

\section{ACKNOWLEDGMENT}

I would like to thank Dr Maha Nasr from Faculty of Pharmacy, Ain Shams University for her assistance.

\section{CONFLICT OF INTERESTS}

Declare none

\section{REFERENCES}

1. Loeser RF, Goldring SR, Scanzello CR, Goldring MB. Osteoarthritis: a disease of the joint as an organ. Arthritis Rheum 2012;64:697-707.

2. Felson DT, Lawrence RC, Dieppe PA, Hirsch R, Helmick CG, Jordan JM, et al. Osteoarthritis: new insights. Part 1: the disease and its risk factors. Ann Intern Med 2000;133:635-46.

3. Bae DK, Yoon KH, Song SJ. Cartilage healing after microfracture in osteoarthritis knees. Arthroscopy 2006;22:367-74.

4. Felson DT. The epidemiology of osteoarthritis: prevalence and risk factors. In: Kuettner KE, Goldberg VM. editors. Osteoarthritic disorders. Rosemont, IL: American Academy of Orthopedic Surgeons; 1995. p. 13-24.

5. Felson DT. An update on the pathogenesis and epidemiology of osteoarthritis. Radiol Clin North Am 2004;42:1-9.

6. Martin JA, Buckwalter JA. Roles of articular cartilage aging and chondrocyte senescence in the pathogenesis of osteoarthritis. Iowa Orthopaedic J 2001;21:1-7.

7. Balazs EA. Viscoelastic properties of hyaluronic acid and biological lubrication. Univ Mich Med Cent J 1968;9:255-9.

8. Balazs EA. The physical properties of synovial fluid and the special role of hyaluronic acid. In: Helfet A. editor. Disorders of the knee. 2nd ed. Philadelphia: JB Lippincott; 1982. p. 61-74.

9. Bradley E, Des Meules M. Arthritis in Canada: an ongoing challenge. Ottawa: Health Canada; 2003;2:7-34.

10. Conaghan PG. Osteoarthritis in 2012: parallel evolution of OA phenotypes and therapies. Nat Rev Rheumatol 2013;9:68-70.

11. Towheed THE. Published meta-analyses of pharmacological therapies for osteoarthritis. Osteoarthritis Cartilage 2002;10:836-7.

12. Towheed TE, Hochberg MC. A systematic review of randomized controlled trial of pharmacological therapy in osteoarthritis of the knee, with an emphasis on trial methodology. Semin Arthritis Rheum 1997;26:755-70.

13. Garner SE, Fidan D, Frankish RR, Judd M, Shea B, Towheed T, et al. Celecoxib for rheumatoid arthritis. Cochrane Database Systematic Rev 2002;(4):CD003831.

14. Lorza C, Altman R. Chondrotection in osteoarthritis. Bull Rheum Dis 1997;46:5-7.

15. Theodosakis J, Adderly B, Fox B. The Arthritis Cure. New York, NY: St Martin's Press; 1997

16. Henrotin Y, Mobasheri A, Marty M. What is the current status of chondroitin sulfate and glucosamine for the treatment of knee osteoarthritis? Maturitas 2014;78:184-7.

17. Toffoletto O, Tavares A, Casarini DE, Redublo BM, Ribeiro AB. Farmacocinetica da associacao de glucosamine e sulfato de condroitina em humanos sadios do sexo masculino. Acta Ortop Bras 2005;13:235-7.

18. Laverty S, Sandy JD, Celeste C, Vachon P, Marier JF, Plaas AHK. Synovial fluid levels and serum pharmacokinetics in a large animal model following treatment with oral glucosamine at clinically relevant doses. Arthritis Rheum 2005;52:181-91.

19. Adebowale A, Du J, Liang Z, Leslie JL, Eddington ND. The bioavailability and pharmacokinetics of glucosamine hydrochloride and low molecular weight chondroitin sulfate after single and multiple doses to beagle dogs. Biopharm Drug Dispos 2002;23:217-25

20. Setnikar I, Giachetti C, Zanolo G. Absorption, distribution and excretion of radioactivity after a single intravenous or oral administration of $[14 \mathrm{C}]$ glucosamine to the rat. Pharmatherapeutica 1984;3:538-50.

21. Setnikar I, Giacchetti C, Zanolo G. Pharmacokinetics of glucosamine in the dog and in man. Arzneimittelforschung 1986;36:729-35.
22. Setnikar I, Palumbo R, Canali S, Zanolo G. Pharmacokinetics of glucosamine in man. Arzneimittelforschung 1993;43:1109-13.

23. Aghazadeh-Habashi A, Sattari A, Pasutto FM, Jamali F. Single dose pharmacokinetics and bioavailability of glucosamine in the rat. J Pharm Sci 2002;5:181-4.

24. Persiani S, Roda E, Rovati LC, Locatelli M, Giacovelli G, Roda A. Glucosamine oral bioavailability and plasma pharmacokinetics after increasing doses of crystalline glucosamine sulfate in man. Osteoarthritis Cartilage 2005;13:1041-9.

25. Bayliss MT, Osborne D, Woodhouse S, Davidson C. Sulfation of chondroitin sulfate in human articular cartilage. The effect of age, topographical position, and zone of cartilage on tissue composition. J Biol Chem 1999;274:15892-900.

26. Burkhardt D, Michel BA, Baici A, Kissling R, Theiler R. Comparison of chondroitin sulphate composition of femoral head articular cartilage from patients with femoral neck fractures and osteoarthritis and controls. Rheumatol Int 1995;14:235-41.

27. Clegg DO, Reda DJ, Harris CL, Klein MA, O'Dell JR, Hooper MM, et al. Glucosamine, chondroitin sulfate, and the two in combination for painful knee osteoarthritis. N Engl J Med 2006;354:795-808.

28. Jackson CG, Plaas AH, Sandy JD, Hua C, Kim-Rolands S, Barnhill JG, et al. The human pharmacokinetics of oral ingestion of glucosamine and chondroitin sulfate taken separately or in combination. Osteoarthritis Cartilage 2010;18:297-302.

29. Simánek V1, Kren V, Ulrichová J, Gallo J. The efficacy of glucosamine and chondroitin sulfate in the treatment of osteoarthritis: are these saccharides drugs or nutraceuticals? Biomed Pap Med Fac Univ Palacky Olomounc Czech Repub 2005;149:51-6.

30. Kelly GS. The role of glucosamine sulfate and chondroitin sulfate in the treatment of degenerative joint disease. Alternative Med Rev 1998;3:27-39.

31. McAlindon TE, LaValley MP, Felson DT. Efficacy of glucosamine and chondroitin for treatment of osteoarthritis. JAMA 2000;284:1241-2.

32. Reginster JY, Deroisy R, Rovati LC, Lee RL, Lejeune E, Bruyere 0 , Giacovelli G, et al. Long-term effects of glucosamine sulphate on osteoarthritis progression: a randomised, placebocontrolled clinical trial. Lancet 2001;357:251-6.

33. Pavelká K, Gatterová J, Olejarová M, Machacek S, Giacovelli G, Rovati LC. Glucosamine sulfate use and delay of progression of knee osteoarthritis: a 3-year, randomized, placebo-controlled, double-blind study. Arch Intern Med 2002;162:2113-23.

34. Towheed TE, Maxwell L, Anastassiades TP, Shea B, Houpt J, Robinson V, Hochberg MC, et al. Glucosamine therapy for treating osteoarthritis. Cochrane Database Syst Rev 2005;2:CD002946.

35. Sawitzke AD, Shi H, Finco MF, Dunlop DD, Harris CL, Singer NG, et al. Clinical efficacy and safety of glucosamine, chondroitin sulphate, their combination, celecoxib or placebo was taken to treat osteoarthritis of the knee: 2-year results from GAIT. Ann Rheum Dis 2010;69:1459-64.

36. Müller-Fassbender H, Bach GL, Haase W, Rovati LC, Setnikar I. Glucosamine compared to ibuprofen in osteoarthritis of the knee. Osteoarthritis Cartilage 1994;2:61-9.

37. Noack W, Fischer M, Förster KK, Rovati LC, Setnikar I. Glucosamine sulfate in osteoarthritis of the knee. Osteoarthritis Cartilage 1994;2:51-9.

38. Reichelt A, Forster KK, Fischer M, Rovati LC, Setnikar I. Efficacy and safety of intramuscular glucosamine sulfate in osteoarthritis of the knee. A randomised, placebo-controlled, double-blind study. Arzneimittelforschung 1994;44:75-80.

39. Hughes R, Carr A. A randomized, double-blind, placebo-controlled trial of glucosamine sulphate as an analgesic in osteoarthritis of the knee. Rheumatology (Oxford) 2002;41:279-84.

40. Bruyere 0, Honore A, Ethgen O, Rovati LC, Giacovelli G, Henrotin $\mathrm{YE}$, et al. Correlation between radiographic severity of knee osteoarthritis and future disease progression. Results from a 3-year prospective, placebo-controlled study evaluating the effect of glucosamine sulfate. Osteoarthritis Cartilage 2003;11:1-5.

41. Cibere J, Kopec JA, Thorne A, Singer J, Canvin J, Robinson DB, et al. Randomized, double-blind, placebo-controlled glucosamine discontinuation trial in knee osteoarthritis. Arthritis Rheum 2004;51:738-45.

42. Bruyere O, Pavelka K, Rovati LC, Deroisy R, Olejarova M, Gatterova $\mathrm{J}$, et al. Glucosamine sulphate reduces osteoarthritis progression in 
postmenopausal women with knee osteoarthritis: Evidence from two 3 y studies. Menopause 2004;11:138-43.

43. Herrero-Beaumont G, Ivorra JA, Del Carmen Trabada M, Blanco FJ, Benito P, Martín-Mola E, et al. Glucosamine sulfate in the treatment of knee osteoarthritis symptoms: a randomized, double-blind, placebo-controlled study using acetaminophen as a side comparator. Arthritis Rheum 2007;56:555-67.

44. Houpt JB, McMillan R, Wein C, Paget-Dellio SD. Effect of glucosamine hydrochloride in the treatment of pain of osteoarthritis of the knee. J Rheumatol 1999;26:2423-30.

45. McAlindon TE, Formica M, LaValley M, Lehmer M, Kabbara K. Effectiveness of glucosamine for symptoms of knee osteoarthritis: results from an internet-based randomized double-blind controlled trial. Am J Med 2004;117:643-9.

46. Hochberg MC, Clegg DO. Potential effects of chondroitin sulfate on joint swelling: a GAIT report. Osteoarthritis Cartilage 2008;16(Suppl 3):22-4.

47. Reichenbach S, Sterchi R, Scherer M, Trelle S, Bürgi E, Bürgi U, et al. Meta-analysis: chondroitin for osteoarthritis of the knee or hip. Ann Intern Med 2007;146:580-90.

48. Kahan A, Uebelhart D, De Vathaire F, Delmas PD, Reginster JY. Long-term effects of chondroitins 4 and 6 sulfate on knee osteoarthritis: the study on osteoarthritis progression prevention, a two-year, randomized, double-blind, placebocontrolled trial. Arthritis Rheum 2009;60:524-33.

49. Messier SP, Mihalko S, Loeser RF, Legault C, Jolla J, Pfruender J, et al. Glucosamine/chondroitin combined with exercise for the treatment of knee osteoarthritis: a preliminary study. Osteoarthritis Cartilage 2007;15:1256-66.

50. Rai J. Efficacy of chondroitin sulfate and glucosamine sulfate in the progression of symptomatic knee osteoarthritis: a randomized, placebo-controlled, double-blind study. Bull Postgrad Inst Med Educ Res Chandigarh 2004;38:18-22.

51. Bucsi L, Poór G. Efficacy and tolerability of oral chondroitin sulfate as a symptomatic slow-acting drug for osteoarthritis (SYSADOA) in the treatment of knee osteoarthritis. Osteoarthritis Cartilage 1998;6:31-6.

52. Bourgeois P, Chales G, Dehais J, Delcambre B, Kuntz JL, Rozenberg S. Efficacy and tolerability of chondroitin sulphate $1200 \mathrm{mg} /$ day vs chondroitin sulfate $3 \mathrm{X} 400 \mathrm{mg} /$ day vs placebo. Osteoarthritis Cartilage 1998;6(Suppl A):25-30.

53. Conrozier T. Anti-arthrosis treatments: efficacy and tolerance of chondroitin sulfates (CS 4 and 6). Presse Med 1998;27:1862-5.

54. Mazieres B, Combe B, Phan Van A, Tondut J, Grynfeltt M. Chondroitin sulfate in osteoarthritis of the knee: a prospective, double-blind, placebo-controlled multicenter clinical study. J Rheumatol 2001;28:173-81.

55. Mathieu P. Radiological progression of internal femorotibial osteoarthritis in gonarthrosis. Chondroprotective effect of chondroitin sulfates ACS4-ACS6. Presse Med 2002;31:1386-90.

56. Uebelhart D, Malaise M, Marcolongo R, de Vathaire F, Piperno $\mathrm{M}$, Mailleux $\mathrm{E}$, et al. Intermittent treatment of knee osteoarthritis with oral chondroitin sulfate: A one-year, randomized, double-blind, multicenter study versus placebo. Osteoarthritis Cartilage 2004;12:269-76.

57. Michel BA, Stucki G, Frey D, de Vathaire F, Vignon E, Bruehlmann $\mathrm{P}$, et al. Chondroitins 4 and 6 sulfate in osteoarthritis of the knee: a randomized, controlled trial. Arthritis Rheum 2005;52:779-86.

58. Mazieres B, Hucher M, Zaim M, Garnero P. Effect of chondroitin sulfate in symptomatic knee osteoarthritis: a multicentre, randomised, double-blind, placebo-controlled study. Ann Rheum Dis 2007;66:639-45.

59. Alekseeva LI, Chichasova NV, Benevolenskaia LI, Nasonov EL, Mendel' OI. Combined medication ARTRA in the treatment of osteoarthrosis. Ter Arkh 2005;77:69-75.

60. Junginger HE. Excipients as absorption enhancers. In: Krishna $\mathrm{R}$, Yu L. EdsZ. Biopharmaceutics applications in drug development. Springer, New York, USA; 2007;74:139-74.

61. Persiani S, Roda E, Rovati LC, Locatelli M, Giacovelli G, Roda A. Glucosamine oral bioavailability and plasma pharmacokinetics after increasing doses of crystalline glucosamine sulfate in man. Osteoarthr Cartil 2005;13,1041-9.

62. Qian S, Zhang $\mathrm{Q}$, Wang Y, Lee B, Betageri GV, Chow MSS, Huang M, Zuo Z. Bioavailability enhancement of glucosamine hydrochloride by chitosan. Int J Pharm (Amsterdam, Neth) 2013;455:365-73.

63. Thanou M, Verhoef JC, Junginger HE. Oral drug absorption enhancement by chitosan and its derivatives. Adv Drug Delivery 2001;52:117-26.

64. Piai JF, Lopes LC, Fajardo AR, Rubira AF, Muniz EC. Kinetic study of chondroitin sulphate release from chondroitin Sulphate/Chitosan complex hydrogel. J Mol Liq 2010;156:28-32.

65. Anisha BS, Sankar D, Mohandas A, Chennazhi KP, Nair SV, Jayakumar R. Chitosan-hyaluronan/nano chondroitin sulfate ternary composite sponges for medical use. Carbohydr Polym 2013;92:1470-6.

66. Park SN, Lee HJ, Lee KH, Suh H. Biological characterization of the EDC-crosslinked collagen-hyaluronic acid matrix in dermal tissue restoration. Biomaterials 2003;24:1631-41.

67. Yeh MK, Cheng KM, Hu CS, Huang YC, Young JJ. Novel proteinloaded chondroitin sulfate-chitosan nanoparticles: preparation and characterization. Acta Biomater 2011;7:3804-12.

68. Collins MN, Birkinshaw C. Morphology of cross-linked hyaluronic acid porous hydrogels. J Appl Polym Sci 2011;120:1040-9.

69. Sharma A, Arora S. Dermal delivery of glucosamine sulphate: formulation, characterization and performance evaluation. World J Pharm Pharm Sci 2013;2:6448-62.

70. Craciunescu O, Gaspar A, Trif M, Moisei M, Oancea A, Moldovan $\mathrm{L}$, et al. Preparation and characterization of a collagenliposome-chondroitin sulphate matrix with potential application for inflammatory disorders treatment. J Nanomater; 2014. http://dx.doi.org/10.1155/2014/903691

71. Yannas IV, Tzeranis DS, Harley BA, So PT. Biologically active collagen-based scaffolds: advances in processing and characterization. Philos Trans R Soc A 2010;368:2123-39.

72. Mozafari MR. Nanoliposomes: preparation and analysis. Methods Mol Biol 2010;605:29-50.

73. Cuppoletti J. Ed. Nanocomposites and Polymers with Analytical Methods. InTech, Rijeka, Croatia; 2011. p. 1.

74. Umerska A, Corrigana OI, Tajbera L. Design of chondroitin sulfate-based polyelectrolyte nanoplexes: formation of nanocarriers with chitosan and a case study of salmon calcitonin. Carbohydrate Polymers 2017;156:276-84.

75. Da Silva GT, Voss GT, Kaplum V, Nakamura CV, Wilhelm EA, Luchese C, et al. Development, characterization and biocompatibility of chondroitin sulfate/poly(vinyl alcohol)/ bovine bone powder porous biocomposite. Mater Sci Eng C 2017;72:526-36.

76. United States Commitee on Health, Education, Labor and Pensions, Subcommittee on Aging. Centre of DiseaseControls role in combating the burden of arthritis. Washington: Department of Health and Human Services; 2004.

77. Jordan KM, Arden NK, Doherty M, Bannwarth B, Bijlsma JW, Dieppe P, et al. Standing committee for international clinical studies including therapeutic trials escisit. eular recommendations 2003:an evidence-based approach to the management of knee osteoarthritis: report of a task force of the standing committee for international clinical studies including therapeutics trials (ESCISIT). Ann Rheum Dis 2003;62:1145-55.

78. Hochberg MC, Altman RD, April KT, Benkhalti M, Guyatt G, McGowan J, et al. American college of rheumatology 2012 recommendations for the use of nonpharmacologic and pharmacologic therapies in osteoarthritis of the hand, hip and knee. Athrtitis Care Res (Hoboken) 2012;64:465-74.

\section{How to cite this article}

- Ahmed M Agiba. Nutraceutical formulations containing glucosamine and chondroitin sulphate in the treatment of osteoarthritis: emphasis on clinical efficacy and formulation challenges. Int J Curr Pharm Res 2017;9(2):1-7. 